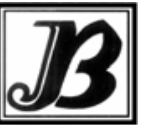

J. bio-sci. 19: 77-80, 2011

ISSN 1023-8654

http://www.banglajol.info/index.php/JBS/index

\title{
EFFECT OF ADULT FEEDING ON PROGENY PRODUCTION AND SEX RATIO OF DINARMUS BASALIS (ROND.) (HYMENOPTERA: PTEROMALIDAE)
}

\author{
MJ Haque, W Islam* \\ Institute of Biological Sciences, University of Rajshahi, Rajshahi 6205, Bangladesh
}

\begin{abstract}
Context: Dinarmus basalis (Rond.) is a larval-pupal ectoparasitoid of the pulse beetles, Callosobruchus (Coleoptera: Bruchidae). This parasitoid could be used in suppressing the pulse beetle populations in stored conditions.

Objective: To observe the influence of different food supplements on the progeny production and sex ratio of $D$. basalis when exposed to the pulse beetles separately.

Materials and Methods: Mated females of $D$. basalis were introduced into separate Petri dishes $(9.5 \mathrm{~cm}$ diam) containing 50 mature mung seeds infested with $C$. chinensis and $C$. maculatus. The parasitoids were provided with host and honey, host and sugarcane, host and egg yolk, host and yeast and host and agar, and host without food individually. After $24 \mathrm{~h}$, the parasitized larvae with seeds were changed and the female parasitoids were provided with foods daily until adults died. After emergence total number of hosts and parasitoids were counted. The sex ratio of $D$. basalis were also calculated and their chi-squared tests were made.

Results: The mean number of progeny production of $D$. basalis on $C$. maculatus-infested blackgram was significantly greater than those reared on $\mathrm{C}$. chinensis-infested mug in all food regimes (Table 1). The progeny production on two host beetles differed significantly in relation to different foods $(F=4.85, P<0.01$. C. chinensis; $F=38.34, P<0.01, C$. maculatus). The most effective food supplement was honey, which enhanced offspring production of $D$. basalis on both the hosts, and egg yolk was the least effective. The percentage of progeny was more or less female-biased in all the treatments except the control.

Conclusion: Food supplementation of $D$. basalis will significantly increase the efficiency of the parasitoid against storage pests including the pulse beetles.
\end{abstract}

Keywords: Food supplements, Dinarmus basalis, Callosobruchus, progeny production, sex ratio.

\section{Introduction}

Many adult parasitoids, particularly Braconidae, Encyrtidae, Eulophidae, Ichneumonidae, Pteromalidae and Trichogrammatidae require nutrients in the form of nectar, pollen or both for optimum progeny production (Jervis et al. 1996). Sugar-rich nectar or honeydew contain low levels of amino acids, proteins and lipids and they might contribute to egg maturation (Wackers 2003). The family Pteromalidae is the largest among the Chalcids and is cosmopolitan in distribution. Its members affect almost all orders of insects either as parasitoids or hyperparasitoids and act as biological control agents. It is known that the synovigenic ectoparasitoid Dinarmus basalis (Rond.) is a promising control agent against Callosobruchus chinensis (L.) (Islam and Kabir 1995) and C. maculatus (F.) and Bruchidius atroleatus (Pic) (Ouedrago et al. 1996, Sanon et al. 1998) and is also reported on C. subnnotatus (Pic), Acanthoscelides obtectus (Say), Zabrotes subfasciatus (Boheman) and other grain-attacking beetles (Rasplus 1989).

Pteromalid parasitoids which feed on floral nectar in field crops and flowering vegetation have high fecundity and effective parasitism rate (Jervis et al. 1996, Zhao et al. 1992). These parasitoids may also feed on the haemolymph of their hosts. In some of these hosts feeding species, nectar is taken during early adult life, whereas host feeding occurs only after the ovaries have developed sufficiently (Flanders 1935). The vast majority of adult parasitoids require sugar solutions that can increase number of eggs laid (Olson and Andow 1998, Schmale et al. 2001).

*Corresponding author Email: mwislam2001@yahoo.com 
Food supplements are reported to affect the sex ratio, behaviour, growth and development of Anisopteromalus calandrae (How.) parasitoid of Sitophilus granarius L. (van den Assem et al. 1984). Information of the various food-sources on progeny production and sex ratio of $D$. basalis is not available. This lead to the present study.

\section{Materials and Methods}

Newly emerged $D$. basalis adults were collected from the stock cultures and kept in the glass jars for 20-24 $\mathrm{h}$ for mating. The stock cultures were maintained in the control temperature (CT room, $30 \pm 0.5^{\circ} \mathrm{C}$ ) on mung and black gram seeds infested by $C$. chinensis and $C$. maculatus separately. Single mated females of $D$. basalis introduced into a petri-dish containing 50 mung seeds infested by 12-24-day-old $C$. chinensis larvae. Similarly, single mated female parasitoid were individually kept in petri-dish containing 20-22-day-old C. maculatus larvae in black gram seeds. Honey, sugarcane stalk, egg yolk, yeast and agar were supplied to the female parasitoids on cotton wool. Control were provided with cotton wool soaked in distilled water.

Infested seeds having host larvae were changed daily and fresh unparasitized mature larvae were provided till female parasitoids died. The infested seeds containing parasitoid larvae were kept in individual vials $(4 \mathrm{~cm}$ $\times 2 \mathrm{~cm}$ ) for 20 days and the number of parasitoids and adult bruchids emerging out were recorded. Female parasitoids that did not produce offspring were not considered. Fifteen females were considered per treatment as replications. The male and female offspring from each replication was recorded separately for determining the sex ratio. The data were analysed by the Duncan's Multiple Range Test.

\section{Results}

The mean number of progeny production of $D$. basalis on $C$. maculatus-infested blackgram was significantly greater than those reared on $\mathrm{C}$. chinensis-infested mug in all food regimes (Table 1). The progeny production on two host beetles differed significantly in relation to different foods $(F=4.85, P<0.01$. C. chinensis; $F=$ 38.34, $P<0.01$, C. maculatus). The most effective food supplement was honey, which enhanced offspring production of $D$. basalis on both the hosts, and egg yolk was the least effective. The results indicated that lipids present in the egg yolk did not support more progeny production. Moreover, all food regimes except egg yolk increased the average lifetime progeny production of the parasitoid on both the hosts as compared with the control. The realized $F_{1}$ progeny of $D$. basalis increased 2.22-fold on $C$. chinensis and 3.18-fold on C. maculatus when honey was provided. The percentage of progeny were more or less female-based in all the treatments except the control.

Table 1. Progeny production and sex ratio of $D$. basalis females fed with different food during oviposition period when exposed to $C$. chinensis and $\mathrm{C}$. maculatus larvae.

\begin{tabular}{lcccc}
\hline \multirow{2}{*}{ Food } & \multicolumn{2}{c}{ C. chinensis } & \multicolumn{2}{c}{ C. maculatus } \\
\cline { 2 - 5 } & $\begin{array}{c}\text { Number of parasitoids/ } \\
\text { female (range) }\end{array}$ & Female (\%) & $\begin{array}{c}\text { Number of parasitoids/ } \\
\text { female (range) }\end{array}$ & Female (\%) \\
\hline Honey & $130.67 \pm 18(42-260)$ & 65.97 & $444.53 \pm 22(279-58)$ & 75.49 \\
Sugarcane & $111.47 \pm 11(58-191)$ & 69.02 & $362.00 \pm 27(173-502)$ & 73.30 \\
Egg yolk & $79.05 \pm 7(44-127)$ & 61.18 & $144.93 \pm 17(30-277)$ & 59.80 \\
Yeast & $91.13 \pm 8(47-146)$ & 66.06 & $233.33 \pm 21(122-335)$ & 70.94 \\
Agar & $77.08 \pm 8(36-130)$ & 58.70 & $179.73 \pm 21(34-328)$ & 57.64 \\
Control & $58.87 \pm 8(18-117)$ & 55.83 & $140.53 \pm 12(46-209)$ & 57.12 \\
\hline
\end{tabular}

Treatments indicated by the same letter in each column do not vary significantly by DMRT 


\section{Discussion}

Food supplements significantly influenced the progeny production of $D$. basalis. The life time progeny production was the lowest on $C$. chinensis + agar, and the highest on $C$. chinensis + honey. The average number of $F_{1}$ progeny of $D$. basalis using $C$. maculatus as the host-feeding was the minimum when egg yolk was provided as food and it was the maximum on honey. The synovigenic $D$. basalis responded to a honey supplement with a 2.22-fold increase on $C$. chinensis and a 3.18-fold increase on C. maculatus in progeny production. Honey and sugarcane seemed to contain adequate nutrients for $D$. basalis. Schmale et al. (2001) reported that $D$. basalis and Anisopteromalus calandrae continued egg deposition on their host and translated into an increase of mean lifetime progeny production by the factors 1.5 and 2.5 respectively, which comply with the present findings. The potential fecundity of Anagyrus pseudococci (Girault), a primary parasitoid of mealybugs, Planococcus citri (Risso) and Pseudococcus affinis (Mask.), was examined on various food sources in the laboratory by Islam and Jahan (1992). They observed that fecundity was higher on the $50 \%$ honey fed parasitoids than those fed on honey dew and water.

In the present study, sugarcane seems to be less suitable than honey for D. basalis, Schmale et al. (2001) also obtained the same results. This is due to the fact that the sugar source solidifies when the sugarcane stem dries out, reducing food accessibility to the parasitoid (Wackers 2000). C. maculatus is considered superior to $C$. chinensis as a host for $D$. basalis since it produces a higher number of $F_{1}$ progeny over its life time, although this species is known to engage in host-feeding on C. chinensis (Wackers et al. 1998). The present experiment focussed that $D$. bassalis produces sufficient progeny on both the hosts when used with suitable supplemental foods. The progeny production of $A$. calandrae increased with different seed-hosts as was noted by Heong (1981) and Smith and Press (1992), which comply with the present study.

Various additional food sources played a significant role on the sex ratio of $D$. basalis. The finding showed that food supplements could hold a great potential for improving this character. Morgan et al. (1981 a, b) recorded $53-66.66 \%$ female progeny production. This is in accordance with the present results. $D$. basalis is synovigenic requiring a source of protein for the continuous production of eggs throught their effective adult life. In the present study, among different diets honey proved to be the best for its egg production. It indicates that a carbohydrate source was necessary for egg production. Besides, D. basalis is an arrhenotokous species. The sex-ratio is determined by the proportion of inseminated females, the ratio of diploid eggs they laid and extrinsic factors which differentially affected survival of eggs, larvae and pupae (Carton et al. 1986). Based on the above findings, $D$. basalis appears to be a promising candidate for biological control of pulse beetles.

\section{References}

Carton Y, Bouletreau M, van Alphen JJM, van Lenteren JC. 1986. The Drosophila parasitic wasps. In: The genetics and biology of Drosophila 111 (Ashburner M, Novitski E. (eds) pp. 347-494. Academic Press, New York.

Flanders SE 1935. An apparent correlation between the feeding habits of certain pteromalids and the condition of their ovarian follicles. Ann Entomol Soc Am 28, 438-444

Heong KL 1981. Searching preference of the parasitoid, Anisopteromalus calandrae (Howard) for different stages of the host, Callosobruchus maculatus (F.) in the laboratory. Res Popul Ecol 23, 177-191. http://dx.doi.org/10.1007/BF02514100.

Islam KS, Jahan M. 1995. Biological control potential of Dinarmus basalis (Rond.) (Hymenoptera: Pteromalidae), a larval-pupal ectoparasitoid of the pulse beetle, Callosobruchus chinensis (L.). Crop Prot 14, 439-443. http://dx.doi.org/10.1016/02612194(94)00007-U.

Jervis MA, Kidd NAC, Heimpel GE. 1996. Parasitoid adult feeding behaviour and biocontrol-a review. Biocontr News Inf 17(1), 11-26.

Morgan PB, Weidhaas DS, Patterson RS. 1981a. Host-parasite relationship: Programmed releases of Spalangia endius Walker and Muscidifuraz raptor Girault and Sanders, against estimated populations of Musca domestica L. J Med Enotmol 18, 158-166.

Morgan PB, Weidhaas, DS, Patterson RS. 1981b. Host-parasite relationship: Augmentative releases of Spalangia endius Walker used in conjunction with population modeling to suppress field populations of Musca domestica L. (Hymenoptera: Pteromalidae and Diptera: Muscidae). J Kansas Entomol Soc 54, 495-504.

Olson DM, Andow DA. 1998. Larval crowding and adult nutrition effects of longevity and fecundity of female, Trichogramma nubilale Ertle \& Davis (Hymenoptera: Trichogrammatidae). Environ Entomol 24, 508-514. 
Ouedrago PA, Sou S, Sanon A, Monge JP, Huinared J, Tran B, Credland PF. 1996. Influence of temperature and humidity on populations of Callosobruchus maculatus (Coleoptera: Bruchidae) and its parasitoid Dinarmus baslis (Pteromalidae) in two climatic zones of Burkina Faso. Bull Entomol Res 86, 695-702. http://dx.doi.org/10.1017/S0007485300039213.

Rasplus JY. 1989. Revision des especes afrotropicals du genre Dinarmus Thomson (Hymenoptera: Pteromalidae). Ann Soc Entomol France 25, 135-162.

Sanon A, Ouedraogo AP, Tricault Y, Credland PF, Huignard J. 1998. Biological control of bruchids in cowpea stores by release of Dinarmus basalis (Hym.: Pteromalidae) adults. Environ Entomol 27, 717-725.

Schmale I, Wackers FL, Cardona C, Dorn S. 2001. Control potential of three Hymenopteran parasitoid species against the bean weevil in stored beans: The effect of adult parasitoid nutrition on longevity and progeny production. $J$ Biol. Cont 21, 134-139. http://dx.doi.org/10.1006/bcon.2000.0911.

Smith L, Press JW. 1992. Functional response of Anisopteromalus calandrae (Hymenopteran Pteromalidae): Influence of host numbers versus host density. J Entomol Sci 27, 375-382.

van den Assem J, Putters FA, Prins TC. 1984. Host quality effects on sex ratio of the parasitic wasp, Anisopteromalus calandrae (Chalcidoidea: Pteromalidae). Netherland J Zool 34, 33-62. http://dx.doi.org/10.1163/002829684X00038.

Wackers FL, Schmale K, Cardona C, Dorn S. 1998. The effect of food supplements on the logevity of the bean weevil parasitoids Anisopteromalus calandrae and Heterospilus prosopidis. IOBC Bull 21, 75- 82.

Wackers FL. 2000. Do oligosaccharides reduce the suitability of honeydew for predators and parasitoids? A further facet to the function of insect-synthesized honeydew sugars. Oikos 90, 197-201. http://dx.doi.org/10.1034/j.1600-0706.2000.900124.x.

Wackers FL. 2003. The parasitoids Need for Sweets: Sugars in Mass Rearing and Biological Control. CAB Publication (ed. Van Lenteren JC, pp.59-71), Netherlands Institute of Ecology, Heteren, The Netherlands.

Zhao JZ, Ayers GS, Grafius EJ, Stehr FW. 1992. Effects of neighboring nectar-producing plants of populations of pest Lepidoptera and their parasitoids in broccoli plantings. Great Lakes Entomologist 25, 253-258. 